\title{
FEVER in children - recommendations for primary care doctors - FEVER COMPASS
}

Recommendations developed by the following experts: Polish Society of Pediatric Pneumology, Polish Pediatric Society, Polish Society of Family Medicine, Polish Society of Clinical Pharmacology and Therapy

ZBIGNIEW DONIEC 1, 2, A, D-F , TERESA JACKOWSKA 3, A, D-F, ADAM SYBILSKI 4, A, D-F,

ORCID ID: 0000-0003-3896-1053 ORCID ID: 0000-0003-0131-7854 ORCID ID: 0000-0003-2389-277X

JAROSŁAW WOROŃ5, A, D-F, AGNIESZKA MASTALERZ-MIGAS6, A, D-F
ORCID ID: 0000-0003-3688-1877
ORCID ID: 0000-0001-6600-2760

${ }^{1}$ Department of Pneumonology of the Institute of Tuberculosis and Lung Diseases, Regional Department

in Rabka-Zdroj, Rabka-Zdroj Poland

${ }^{2}$ Institute of Health Sciences, Podhale State College of Applied Sciences in Nowy Targ, Nowy Targ, Poland

${ }^{3}$ Department of Paediatrics, Medical Centre for Postgraduate Education, Warsaw, Poland

${ }^{4}$ Second Department of Paediatrics, Medical Centre for Postgraduate Education, Warsaw, Poland

${ }^{5}$ Chair of Pharmacology, Department of Clinical Pharmacology, Jagiellonian University Medical College, Cracow,

Poland

${ }^{6}$ Department of Family Medicine, Wroclaw Medical University, Wroclaw, Poland

A - Study Design, B - Data Collection, C - Statistical Analysis, D - Data Interpretation, E - Manuscript Preparation, F - Literature Search, G - Funds Collection

Summary In children, fever is a symptom of a wide spectrum of diseases, ranging from common self-limiting viral upper respiratory tract infections to serious life-threatening diseases. The aim of the diagnostic procedure is to identify the cause of fever, determine indications for outpatient treatment, plan the appropriate pharmacological therapy or reveal the need for hospitalisation. Paracetamol and ibuprofen are antipyretics recommended for symptomatic treatment of children; however, the medications should not be used in combination or alternately, except in specific clinical situations. The drugs may be applied to treat fever and topical reactions after vaccination, but not prophylactically in order to reduce the incidence of fever or local discomfort after vaccination. Both medications can be used in patients with asthma, with the exception of intolerant children. Children with confirmed or suspected COVID-19 may be treated with paracetamol and ibuprofen in accordance with clinical indications and dosage recommendations.

Key words: fever, children, antipyretics, vaccinations, COVID-19.

Doniec Z, Jackowska T, Sybilski A, Woroń J, Mastalerz-Migas A. FEVER in children - recommendations for primary care doctors - FEVER COMPASS. Fam Med Prim Care Rev 2021; 23(1): 99-115, doi: https://doi.org/10.5114/fmpcr.2021.102648.

\section{Background}

In children, fever is a manifestation of a broad illness spectrum, including both frequent self-limiting viral upper respiratory tract infections and serious, life-threatening conditions. As such, it is a source of concern for parents and carers, being one of the most common reasons of appointments in clinics, as well as, in the time of the SARS-CoV-2 pandemic, telemedicine services, i.e. remote consultations. Fever is also one of the most common reasons for hospital emergency department visits and admissions to paediatric wards, in addition to breathing difficulties. Therefore, it seems very important to review temperature measurement methods, criteria of fever diagnosis and classification as well as management of feverish children, including special situations [1].

\section{Body temperature and its measurement methods}

Body temperature, maintained at a relatively stable level in a normal temperature environment, is controlled by the hypothalamic thermoregulatory centre, responsible for the balance between heat production (mainly through metabolic processes in the muscles and liver) and its loss via skin and the respiratory system [2].
In general, it is assumed that the average normal temperature on the body surface is $37^{\circ} \mathrm{C}$, although infants and young children usually demonstrate a higher temperature than older children and adults [2-4]. Physiologically, daily temperature varies within $0.5^{\circ} \mathrm{C}$ to $1^{\circ} \mathrm{C}$; its lowest and highest values are observed between 2-6 a.m. and 5-7 p.m., respectively. It may differ individually, e.g. due to physical activity and, in girls, menstrual cycle phase $[3,5]$. The highest temperature is detected in the hypothalamic thermoregulatory centre; the term "core temperature" refers to the value measured in the pulmonary artery (hypothalamic temperature is not available for measurements). As core temperature cannot be measured in daily practice, other standard body surface measurement sites are utilised instead [3].

Temperature measurements are essential for proper examination and assessment of a child's condition, and their results depend on the measurement site (Table 1). Currently, body temperature can be measured at four sites: rectum, axilla, mouth and ear (tympanic membrane) (Table 2). In infants under the age of 4 weeks, the National Institute of Health and Care Excellence (NICE) recommends body temperature measurements in the axilla using an electronic thermometer. In children aged 4 weeks to 5 years, healthcare professionals should measure body temperature by one of the following methods [6]:

- electronic thermometer in the axilla,

- chemical dot thermometer in the axilla,

- infra-red tympanic thermometer. 


\begin{tabular}{|l|l|l|l|}
\hline \multicolumn{3}{|l|}{ Table 1. Body temperature values defined as normal temperature and fever as per measurement site [3] } \\
\hline Measurement site & Normal temperature range $\left({ }^{\circ} \mathrm{C}\right)$ & Average temperature $\left({ }^{\circ} \mathrm{C}\right)$ & Fever $\left({ }^{\circ} \mathrm{C}\right)$ \\
\hline Rectum & $36.6-37.9$ & 37.0 & $\geq 38.0$ \\
\hline Mouth & $35.5-37.5$ & 36.6 & $\geq 37.6$ \\
\hline Axilla & $34.7-37.3$ & 36.4 & $\geq 37.4$ \\
\hline Ear (tympanic membrane) & $35.7-37.5$ & 36.6 & $\geq 37.6$ \\
\hline
\end{tabular}

\begin{tabular}{|l|l|l|}
\hline \multicolumn{2}{|l|}{ Table 2. Body temperature measurement sites in children [6] } & Disadvantages \\
\hline Measurement type & Advantages & $\begin{array}{l}\text { Requires supervision (due to displacement potential). Lon- } \\
\text { ger-lasting measurements than in other methods (approx. } \\
\text { 30 to 40 s). Inaccurate measurements possible. Inaccuracy } \\
\text { increases with sweating and evaporation }\end{array}$ \\
\hline Feonates: as accurate as rectal measurements & Convenient, easy to use, safe, quick readings & $\begin{array}{l}\text { Inaccurate measurements and frequent false normal tem- } \\
\text { perature readings despite increased core body tempera- } \\
\text { ture. Not recommended }\end{array}$ \\
\hline Oral or sublingual & $\begin{array}{l}\text { Easily available, accurate (good correlation with } \\
\text { core temperature) } \\
\text { No effects of ambient temperature on readings }\end{array}$ & $\begin{array}{l}\text { Requires cooperation (unsuitable for children under the age } \\
\text { of 5 years and uncooperative children). Hot baths, exercise, } \\
\text { hot and cold drinks and breathing through the mouth af- } \\
\text { fect readings. Accuracy depends on closed mouth. Do not } \\
\text { use in the case of tachypnoea due to decreased mouth } \\
\text { temperature. Temperature variations observed with various } \\
\text { thermometer locations }\end{array}$ \\
\hline Rectal & $\begin{array}{l}\text { Gold standard for measurement accuracy, no } \\
\text { effects of ambient temperature on readings, no } \\
\text { age limitations (except neonates) }\end{array}$ & $\begin{array}{l}\text { Not child-friendly, with potential psychologically harmful ef- } \\
\text { fects. Discomfort and pain possible for patients with rectal } \\
\text { infection or irritation. Hygiene-lacking measurements with } \\
\text { a risk of infection. A time-consuming and privacy-requiring } \\
\text { procedure. Readings depend on the depth of thermometer } \\
\text { insertion, local blood flow and presence of stool or diar- } \\
\text { rhoea. Do not use in neutropenic patients }\end{array}$ \\
\hline $\begin{array}{l}\text { Ear (tympanic mem- } \\
\text { brane) }\end{array}$ & $\begin{array}{l}\text { Quick and easy to use without cross-contamina- } \\
\text { tion risk, independent of ambient temperature }\end{array}$ & $\begin{array}{l}\text { Sometimes inaccurate measurements (technical errors), } \\
\text { particularly in children under the age of 2 to 3 years }\end{array}$ \\
\hline
\end{tabular}

Temperature measurements in the rectum (back passage) are usually performed in infants and young children when a result may be doubtful at other sites, may inadequately reflect the child's condition or will be the basis for radical clinical intervention. Rectal thermometry is contraindicated in neutropenic children (with cancer), as well as neonates and young infants (injury risk) [1, 5, 7, 8].

The oral route of temperature measurements is preferred in children older than 5 years of age. Temperature in the mouth is usually lower than in the rectum by $0.6^{\circ} \mathrm{C}$ due to breathing through the mouth, and its value can be affected by recent hot or cold fluid consumption, hot baths and physical exercise $[4,9]$.

Results of body temperature measurements in the ear (a thermometer must detect an infra-red beam reflected by the tympanic membrane) are comparable to core temperature values, although commonly used infra-red devices are far less accurate, particularly in young children, which makes this technique not a gold standard yet $[3,4]$.

Contact or non-contact forehead thermometers measure the amount of heat emitted by temporal arteries. Temporal (on the forehead) measurement readings can be higher or lower than in the rectum, suggesting they should not be taken into account during clinical decision-making $[4,10,11]$. Similarly, body temperature measurements with the use of smartphone applications cannot be recommended (based on the current knowledge and research).

Properly measured body temperature requires an appropriate instrument, i.e. a thermometer. Recommended thermometer features and body temperature measurement methods in children are presented in Tables 3 and 4.

\section{Table 3. Recommended thermometer features [3]}

Accurate readings of body temperature for all age groups Convenient and easy to use by the patient and clinician Quick readings

No risk of cross-contamination

Not affected by ambient temperature

Safe measurements

Proper quality-to-price ratio

High level of reliability

Table 4. Recommended body temperature measurement methods $[1,5,6]$

\begin{tabular}{|l|l}
\hline Child's age & Recommended body temperature measure-
\end{tabular} ment methods

\begin{tabular}{|l|l|}
\hline Neonates & $\begin{array}{l}\text { Electronic or chemical dot thermometer in the } \\
\text { axilla }\end{array}$ \\
\hline Infants & $\begin{array}{l}\text { Electronic thermometer in the rectum } \\
\text { (>6 months old) } \\
\text { Infra-red thermometer in the ear } \\
\text { Electronic or chemical dot thermometer in the } \\
\text { axilla }\end{array}$ \\
\hline $\begin{array}{l}<5 \text { years old or } \\
\text { uncooperative } \\
\text { children }\end{array}$ & $\begin{array}{l}\text { Electronic thermometer in the rectum } \\
\text { Infra-red thermometer in the ear } \\
\text { Electronic or chemical dot thermometer in the } \\
\text { axilla }\end{array}$ \\
\hline $\begin{array}{l}>5 \text { years old, } \\
\text { cooperative } \\
\text { children }\end{array}$ & $\begin{array}{l}\text { Infra-red thermometer in the ear } \\
\text { Electronic thermometer in the mouth }\end{array}$ \\
\hline
\end{tabular}




\section{Fever}

Fever (Latin: febrile) is an elevation of core body temperature above the normal daily variation with proper body thermoregulation. It is also a component of a specific biological response to illness that facilitates and promotes recovery.

The level of raised temperature considered as abnormal depends on the child's age and the measurement site. In neonates and infants younger than 3 months of age, fever is defined as rectal temperature of $>38^{\circ} \mathrm{C}$. In infants above 3 months of age and children younger than 3 years of age, fever is identified within the range of $>38.0$ to $39.0^{\circ} \mathrm{C}$. Serious fever is defined as a described as body temperature of $>39.0^{\circ} \mathrm{C}$ with no focal infection detected during a physical examination [5]. In children older than 3 years of age, fever is defined as an oral temperature above $38^{\circ} \mathrm{C}$ [7].

Clinically, fever is defined as a temperature above the normal average or normal temperature at the measurement site by at least $1^{\circ} \mathrm{C}$ (Table 1 ) or a core temperature (measured in the pulmonary artery) of $>38.3^{\circ} \mathrm{C}[2]$.

In pathophysiology, fever is a response of the body involving a temperature increase due to activation of the hypothalamic thermoregulatory centre and its shift to a higher set-point. This occurs as a reaction to exogenous pyrogens: viruses, bacteria and their toxins, allergens, immune complexes, active components of the complement system; and to endogenous pyrogens released by stimulated monocytes and macrophages, cytokines such as interleukin 1 (IL-1), interleukin 6 (IL-6) and tumour necrosis factor $\alpha$ (TNF- $\alpha)$. The above cytokines induce expression of hypothalamic cyclooxygenase 2 (COX-2) and, through the CAMP system, production of prostaglandin E2 (PGE2), which primarily acts on the preoptic area of the hypothalamus. As a result, the thermoregulatory centre is activated and shifted to a higher set-point. This in turn triggers an active process aiming to reach a new, higher temperature value which is achieved by minimising heat loss with physiological vasoconstriction and heat production during tremors [5, 7]. Potential fever benefits include retardation of certain bacterial and viral growth and proliferation (possibly related to lower iron serum concentrations), as well as enhanced immune responses at moderately elevated temperatures. Some of beneficial effects disappear with higher body temperatures (approx. $40^{\circ} \mathrm{C}$ ) [5]. However, fever is associated with many symptoms, such as myalgia, headache, nausea, feeling cold (even rigors), which is a source of anxiety for the child and their parents/carers.

In most children, fever is triggered by infections (caused by viruses, bacteria, parasites, tuberculosis) and, far less frequently, by non-infectious diseases (autoimmune, malignant, allergic, drug-induced, vaccine-induced conditions); therefore, a febrile child is always suspected of underlying infectious illness until another cause is determined. It is estimated that over $30 \%$ of cases are fevers of unknown origin (FUOs).

In neonates and infants younger than 3 months of age, fever can be the only sign of a serious bacterial infection (SBI), such as urinary tract infection, bacteraemia, meningitis or pneumonia. The probability of this kind of infection is much higher (particularly in neonates) than in other age groups [11-13]. SBI risk factors are: prematurity, prolonged foetal membrane rupture, maternal streptococci B colonisation, breastfeeding difficulty, respiratory disorders, apnoea. In infants above 3 months and children younger than 3 years of age, most infections are selflimiting conditions, and recovery occurs without special causal treatment. However, it should be noted that fever can be a sign of a life-threatening condition in this age group [14]. In a child under the age of five, fever is usually related to an inflammatory response to a viral, bacterial or parasitic infection or, less frequently, to a non-infectious agent.

\section{Fever clinical classification}

In daily clinical practice, the following classification, including three categories, can be helpful:

- Fever with localising signs and symptoms: the most common in children, typically short-lasting fever (frequently viral infections or targeted treatment); the cause is usually identified based on a history taken and physical examination (occasionally X-ray).

- Fever without localising signs and symptoms: frequently occurring in children during the first 36 months of life (approx. 20\% of cases); the most common causes are viral infections; urinary tract infections and bacteraemia should always be ruled out.

- Persistent fever of unknown origin: diagnosed when fever persists for longer than 1 week with no other aetiology-suggesting symptoms identified (in physical examination and additional tests).

The most common causes of the three fever types are presented in Table 5.

The clinical relevance of characteristic fever patterns has changed over the years, as there is only a small number of diseases with such a pattern, while many conditions demonstrate similar patterns. Despite the fact that the development of diagnostic testing has resulted in opportunities for establishing a diagnosis before variable body temperatures reveal its characteristic pattern, this knowledge may be helpful in differential diagnosis (Table 6).

\begin{tabular}{|c|c|}
\hline Fever type & Causes \\
\hline $\begin{array}{l}\text { Fever with localising signs and } \\
\text { symptoms (usually }<1 \text { week) }\end{array}$ & $\begin{array}{l}\text { - Upper respiratory tract infections: viral upper respiratory tract infections, otitis media, tonsillitis, } \\
\text { - Reste laryngitis, stomatitis } \\
\text { - Gastrointestinal tract: gastroenteritis, hepatitis, appendicitis } \\
\text { - CNS: meningitis, encephalitis } \\
\text { - Infectious diseases: parotitis, varicella } \\
\text { - Autoimmune diseases: rheumatic diseases, Kawasaki disease }\end{array}$ \\
\hline $\begin{array}{l}\text { Fever without localising } \\
\text { signs and symptoms (usually } \\
<1 \text { week) }\end{array}$ & $\begin{array}{l}\text { - Infections: bacterial infections (sepsis), urinary tract infections, viral infections, malaria } \\
\text { - Juvenile idiopathic arthritis } \\
\text { - Drug- and vaccine-induced fever }\end{array}$ \\
\hline $\begin{array}{l}\text { Persistent fever of unknown } \\
\text { origin (usually }>1 \text { week) }\end{array}$ & $\begin{array}{l}\text { Infections (60-70\%): } \\
\text { - Localised: rhinosinusitis, endocarditis, abscess } \\
\text { - Generalised: viral infections (e.g. EBV), TB, Kawasaki disease, brucellosis, bartonellosis } \\
\text { (B. henselae) } \\
\text { - Collagenoses (20\%): juvenile idiopathic arthritis, systemic lupus erythaematosus } \\
\text { - Proliferative disorders (5\%): leukaemia, lymphomas, neuroblastomas } \\
\text { - Miscellaneous (5-10\%): drug-induced fever, artificially-induced fever, autoimmune diseases }\end{array}$ \\
\hline
\end{tabular}




\begin{tabular}{|l|l|}
\hline \multicolumn{2}{|l|}{ Table 6. Fever patterns observed in paediatric diseases ([2] as modified by the authors) } \\
\hline Fever pattern & Diseases \\
\hline Continuous & Typhoid, malaria (Plasmodium falciparum) \\
\hline Remittent & Most viral and bacterial infections \\
\hline Intermittent & Malaria, lymphoma, endocarditis \\
\hline Hectic & Kawasaki disease, bacterial infections (sepsis) \\
\hline Daily & Malaria (Plasmodium vivax) \\
\hline Daily double & Leishmaniasis, juvenile idiopathic arthritis, drug-induced fevers \\
\hline Relapsing & Brucellosis, malaria (Plasmodium vivax, Plasmodium ovale, Plasmodium malariae) \\
\hline Recurrent & Familial Mediterranean fever \\
\hline
\end{tabular}

When classifying fever patterns, its onset (rapid or slow), daily temperature variation and variation throughout the whole illness, fever cycles and treatment response should be considered. Fever patterns are classified as follows:

- Continuous or sustained fever is characterised by persistently higher body temperature with maximum fluctuations of $0.4^{\circ} \mathrm{C}$ per 24 hours. This pattern is usually unrelated to rigors or tremors. Normal daily temperature variation is typically absent. This variant is characteristic of typhoid and may be associated with bacterial endocarditis, tuberculosis (TB) and drug-induced fever.

- Remittent fever is manifested by a daily temperature decrease, though not to normal values. The fever amplitude is higher than $0.3^{\circ} \mathrm{C}$ and lower than $1.4^{\circ} \mathrm{C}$. It is the most common fever type encountered in paediatric practice and uncharacteristic of any disease. A daily temperature variation is usually observed, particularly with fever caused by an infectious agent.

- Intermittent fever: temperature falls to normal daily, typically in the morning, with a peak in the afternoon. Its amplitude is the same as for remittent fever. It is the second most common fever type observed in clinical practice.

- Hectic fever is when remittent or intermittent fever demonstrates a very high amplitude $\left(>1.4^{\circ} \mathrm{C}\right)$.

- Daily (intermittent) fever is defined as episodes of daily fever. This type is caused by malarial infections (Plasmodium vivax) but can also originate from viral and bacterial infections.

- Daily double fever is characterised by two temperature increases per 24 hours (12-hour cycles). It can occur in the case of malaria or certain treatments (e.g. carbamazepine).

- Undulant fever is manifested by a gradual temperature raise that remains at a high level for a few days and then gradually falls to normal values (e.g. brucellosis).

- Relapsing or periodic fever is defined as three or more fever episodes within 6 months and asymptomatic periods lasting at least 7 days. It can be caused by infectious (viral upper respiratory tract, Epstein-Barr or bacterial infections, e.g. urinary tract infections) or non-infectious (autoimmune inflammatory diseases) factors.

- Recurrent fever: a certain variant of relapsing fever with rapid onset and high temperatures $\left(\geq 40^{\circ} \mathrm{C}\right)$ which recurs as 3- to 6-day episodes followed by an asymptomatic period of similar duration. The term is usually used to describe the course of Borrelia infections and tick-borne diseases.

- Periodic fever is also a recurrent type, but it often recurs in a rhythmic manner. It most commonly appears in early childhood, typically at $<1$ year of age, and is caused by autoimmune diseases, e.g. cryopyrin-associated periodic syndromes (CAPS), periodic fever with aphthous stomatitis, pharyngitis and cervical adenitis (PFAPA).

\section{Fever phases}

There are three fever phases [2]: temperature increase, stabilisation and decrease.

- The phase of temperature increase is characterised by discomfort and results from reduced heat loss through vasoconstriction and enhanced heat production via tremors. A child feels cold, and the skin is also cold.

- The phase of temperature stabilisation occurs with a new (higher) set-point in the thermoregulation system. Heat production and loss are balanced as in a normal state but at a higher temperature level. Reddish or pink skin denotes a fever peak. After reaching this point, a child usually feels comfortable, without tremors.

- The phase of temperature decrease to a normal level can be a gradual process lasting 2 to 3 days. It is accompanied by sweats.

\section{Diagnostic assessment}

\section{General recommendations}

Since March 2020 and the spread of the SARS-CoV-2 pandemic, the diagnostic process more widely utilises remote services (telephone and online appointments) as a fully recognised form of medical consultation in addition to traditional visits and examinations.

The aims of diagnostic assessment regarding a child's general condition and age, co-morbidities and previous immunisation are as follows [6]:

- To assess the presence or absence of immediately life-threatening signs and symptoms.

- To assess the risk of serious illness.

- To assess signs and symptoms suggestive of specific diseases that can be identified with or without necessary additional testing.

- To assess the likelihood of a child presenting non-specific features of acute, self-limiting viral disease.

- To determine a proper medical intervention based upon a child's assessment [immediate treatment of life-threatening condition), oxygen therapy with $\mathrm{SpO}_{2}$ $<92 \%$, referring a child to the emergency medical team and admission to the intensive care unit, hospitalisation, ambulatory care with home follow-up (on a remote and/ /or ambulatory basis).

Such defined aims of diagnostic assessment mean that a child presenting signs and symptoms not indicative of a serious illness (concerning unequivocal clinical features in particular) will not be burdened with unnecessary medical intervention, and a child with an unclear diagnosis can be supervised by a primary care physician, provided that reassessment in the case of a worsening of the illness can be provided.

Children with a life-threatening condition, with unclear diagnosis following initial assessment and a differential diagnosis including serious illness (with a suspected specific disease that 
requires necessary confirmatory testing unavailable in the ambulatory setting) and children with a clear diagnosis but requiring inpatient treatment should be referred to hospital on the basis of the physician's assessment [15].

Assessment of a feverish child in the primary care setting includes:

1) Medical history:

- Medical history with assessment of time from the onset of signs and symptoms as well as fever, fever pattern, symptomatic and antibiotic treatment

- Contact with a person affected by COVID-19 in the last 2 weeks, isolation or quarantine in a child's family or environment

- Comorbidities (chronic respiratory diseases, immune deficiencies, other)

- Previous immunisation

- Other sign and symptoms (rigors, myalgia, headache, poor feeding, lethargy, fatigue, polydipsia, delirium, oliguria).

2) Physical examination to assess the following:

- General condition

- Level of consciousness

- Colour of skin, facial erythema, warmth of limbs

- Skin turgor

- Activity level (lethargy, irritability)

- Respiratory system: respiratory rate, tachypnoea (approx. 2.5 breaths/minute per each temperature increase of $1^{\circ} \mathrm{C}$ ), breathing pattern, grunting, change on auscultation, etc.
- Circulation: heart rate, tachycardia (increase by 10 beats/minute per each temperature elevation of $1^{\circ} \mathrm{C}$ ), pulse volume, presence of innocent heart murmur and third heart sound, high blood pressure)

- Capillary refill time

- Hydration

- Paraesthesia.

3) Temperature measurement.

4) Blood pressure measurement (in the case of heart rate or capillary refill time abnormalities).

5) Additional testing (complete blood count, urinalysis, blood culture, inflammatory markers, ECG, chest X-ray, ultrasound, etc.).

6) Age-based assessment of risk of serious illness.

7) Assessment of signs and symptoms suggestive of specific diseases.

Characteristics of feverish children at high, intermediate or low risk of serious illness are presented in Table 7.

a) High-risk group: children presenting any "high-risk" sign or symptom.

b) Intermediate-risk group: children presenting any "intermediate-risk" sign or symptom, with no "high-risk" features.

c) Low-risk group: children presenting "low-risk" signs and symptoms, with no "intermediate-risk" or "highrisk" features.

Signs and symptoms, as well as selected additional assessments suggestive of specific diseases, are presented in Tables 8 and 9.

\begin{tabular}{|c|c|c|c|}
\hline \multirow[t]{2}{*}{ Assessed feature/system } & \multicolumn{3}{|l|}{ Signs and symptoms } \\
\hline & Low risk & Intermediate risk & High risk \\
\hline $\begin{array}{l}\text { Colour of lips, skin or } \\
\text { tongue }\end{array}$ & - Normal colour & $\begin{array}{l}\text { - Pallor reported by parent/ } \\
\text { /carer }\end{array}$ & - Pale/mottled/ashen/blue skin \\
\hline Activity & $\begin{array}{l}\text { - Responds normally to social } \\
\text { cues } \\
\text { - Content/smiles } \\
\text { - Stays awake or awakens } \\
\text { quickly } \\
\text { - Strong normal cry/not crying }\end{array}$ & $\begin{array}{l}\text { - Not responding normally to } \\
\text { social cues } \\
\text { - No smile } \\
\text { - Wakes only with prolonged } \\
\text { stimulation } \\
\text { - Decreased activity }\end{array}$ & $\begin{array}{l}\text { - No response to social cues } \\
\text { - Appears ill and not responsive } \\
\text { to a healthcare professional } \\
\text { - Does not wake or, if roused, } \\
\text { does not stay awake } \\
\text { - Weak, high-pitched or con- } \\
\text { tinuous cry }\end{array}$ \\
\hline Respiratory system & & $\begin{array}{l}\text { - Nasal flaring } \\
\text { - Tachypnoea: } \\
\text { - } \quad \text { RR }>50 \text { breaths minute, } \\
\quad 6-12 \text { months of age } \\
\text { - } \quad \text { RR }>40 \text { breaths/minute, } \\
>12 \text { months of age } \\
\text { - Oxygen saturation } \leq 95 \% \text { in air } \\
\text { - Crackles in the chest }\end{array}$ & $\begin{array}{l}\text { - Grunting } \\
\text { - Tachypnoea: } \\
\text { - } \quad \text { RR }>60 \text { breaths/minute } \\
\text { - } \text { Moderate or severe chest } \\
\quad \text { indrawing }\end{array}$ \\
\hline Circulation and hydration & $\begin{array}{l}\text { - Normal skin and eyes } \\
\text { - Moist mucous membranes }\end{array}$ & $\begin{array}{l}\text { - Dry mucous membranes } \\
\text { - Tachycardia: } \\
\text { - } \quad \text { HR }>160 \text { beats/minute, } \\
\quad<1 \text { year of age } \\
\text { - } \quad H R>150 \text { beats/minute, } \\
\quad 1-2 \text { years of age } \\
\text { - } \quad H R>140 \text { beats/minute, } \\
\quad 2-5 \text { years of age } \\
\text { - Capillary refill time } \geq 3 \text { seconds } \\
\text { - Poor feeding in infants } \\
\text { - Reduced urine output }\end{array}$ & - Reduced skin turgor \\
\hline Other & $\begin{array}{l}\text { - None of the intermediate or } \\
\text { high-risk symptoms or signs }\end{array}$ & $\begin{array}{l}\text { - } 3-6 \text { months of age, tempera- } \\
\text { ture } \geq 39^{\circ} \mathrm{C} \\
\text { - } \text { Fever for } \geq 5 \text { days } \\
\text { - } \text { Rigors } \\
\text { - } \\
\text { - } \\
\text { Nedema of a limb or joint } \\
\text { using an extremity }\end{array}$ & $\begin{array}{l}\text { - } \quad 3 \text { months of age, tempera- } \\
\text { ture } \geq 38^{\circ} \mathrm{C} \\
\text { - Non-blanching rash } \\
\text { - } \text { Bulging fontanelle } \\
\text { - Neck stiffness } \\
\text { - Status epilepticus } \\
\text { - Focal neurological signs } \\
\text { - Focal seizures }\end{array}$ \\
\hline
\end{tabular}




\begin{tabular}{|c|c|}
\hline Diagnosis & Signs and symptoms \\
\hline $\begin{array}{l}\text { Meningococcal disease (sepsis, } \\
\text { meningitis) }\end{array}$ & $\begin{array}{l}\text { - Non-blanching rash, particularly with one or more of the following: } \\
\text { - } \text { an ill-looking child, overall impression of serious illness } \\
\text { - } \text { skin lesions larger than } 2 \mathrm{~mm} \text { in diameter (purpura) } \\
\text { - capillary refill time of } \geq 3 \text { seconds } \\
\text { - neck stiffness }\end{array}$ \\
\hline Bacterial meningitis* & $\begin{array}{ll}\text { - } & \text { Neck stiffness } \\
\text { - } & \text { Bulging fontanelle } \\
\text { - } & \text { Decreased level of consciousness } \\
\end{array}$ \\
\hline Herpes simplex encephalitis & $\begin{array}{l}\text { - } \quad \text { Focal neurological signs } \\
\text { - } \quad \text { Focal seizures } \\
\text { - } \quad \text { Consciousness impairment } \\
\end{array}$ \\
\hline Septic arthritis/osteomyelitis & $\begin{array}{l}\text { - Oedema of a limb or joint } \\
\text { - Not using an extremity/Non-weight bearing }\end{array}$ \\
\hline $\begin{array}{l}\text { Urinary tract infection }>3 \text { months of } \\
\text { age** }\end{array}$ & $\begin{array}{l}\text { - Vomiting } \\
\text { - } \text { Poor feeding } \\
\text { - Lethargy } \\
\text { - Irritability } \\
\text { - Ibdominal pain or tenderness } \\
\end{array}$ \\
\hline Kawasaki disease $* * *, * * * *$ & $\begin{array}{l}\text { - Fever for more than } 5 \text { days and at least } 4 \text { of the following: } \\
\text { - } \text { bilateral conjunctival injection without exudate } \\
\text { - } \text { erythema and cracking of lips, strawberry tongue, oropharyngeal mucositis } \\
\text { - oedema and erythema in the hands and feet } \\
\text { - } \text { polymorphous rash } \\
\text { - } \text { cervical lymphadenopathy }\end{array}$ \\
\hline COVID-19 & $\begin{array}{l}\text { - Confirmed SARS-CoV-2 infection (nasopharyngeal swab: RT-PCR, antigen test) } \\
\text { - Loss of smell or taste } \\
\text { - } \text { Pneumonia } \\
\text { - } \text { Abdominal pain } \\
\text { - } \text { Geurtrointestinal symptoms } \\
\text { - Other symptoms }\end{array}$ \\
\hline $\begin{array}{l}\text { PIMS-TS (paediatric inflammatory } \\
\text { multisystem syndrome temporally } \\
\text { associated with SARS-CoV-2) }\end{array}$ & $\begin{array}{l}\text { - Confirmed SARS-CoV-2 infection (RT-PCR, IgG, IgM) } \\
\text { - Contact or no confirmed contact with a SARS-CoV-2 infected person } \\
\text { - } \text { - shildren presenting with Kawasaki disease symptoms and/or (separately or in combination): } \\
\text { - } \text { abdominal pain } \\
\text { - gastrointestinal symptoms } \\
\text { - pneumonia } \\
\text { - neurological symptoms }\end{array}$ \\
\hline
\end{tabular}

* Classical signs of meningitis (neck stiffness, bulging fontanelle, high-pitched cry) are often absent in infants with bacterial meningitis.

** Urinary tract infection should be considered in any feverish child younger than 3 months of age.

*** Check for the presence of features since the onset of fever, as they may have resolved by the time of assessment.

$* * * *$ Children younger than 1 year of age may present fewer clinical features, but they are at a higher risk of coronary artery abnormalities.

\begin{tabular}{|l|l|}
\hline \multicolumn{2}{|l|}{ Table 9. Signs and symptoms of respiratory tract diseases in feverish children ([6] as modified by the authors) } \\
\hline Diagnosis & Signs and symptoms \\
\hline Rhinosinusitis & Rhinorrhoea (nasal discharge or obstruction) \\
& Nasal obstruction \\
& Smell impairment \\
Sneezing \\
Facial pressure or oedema \\
Cough
\end{tabular}




\begin{tabular}{|c|c|}
\hline Diagnosis & Signs and symptoms \\
\hline Acute subglottic laryngitis & $\begin{array}{l}\text { - Rhinosinusitis } \\
\text { - Barking cough } \\
\text { - Dysphonia } \\
\text { - Aphonia } \\
\text { - Rhonchi } \\
\text { - Dyspnoea }\end{array}$ \\
\hline Tracheitis and bronchitis & $\begin{array}{l}\text { - Coryza } \\
\text { - Dry and productive cough } \\
\text { - Abnormal bronchial sounds on auscultation }\end{array}$ \\
\hline Bronchiolitis & $\begin{array}{l}\text { - Prodromal signs and symptoms of viral nasopharyngeal infection } \\
\text { - Cough } \\
\text { - Rhonchi } \\
\text { - Dyspnoea } \\
\text { - Tachypnoea } \\
\text { - Bradypnoea }\end{array}$ \\
\hline Pneumonia & $\begin{array}{l}\text { - Tachypnoea (> } 60 \text { breaths/minute, } 0-5 \text { months of age; } \\
>50 \text { breaths/minute, } 6-12 \text { months of age; } \\
>40 \text { breaths/minute, }>12 \text { months of age) } \\
\text { - Cracks on chest auscultation } \\
\text { - Rhinitis } \\
\text { - Dyspnoea, chest indrawing } \\
\text { - Cyanosis } \\
\text { - Saturation } \mathrm{O}_{2} \leq 95 \%\end{array}$ \\
\hline Influenza & $\begin{array}{l}\text { - Rapid symptom onset } \\
\text { - Cough } \\
\text { - Myalgia, arthralgia } \\
\text { - Poor feeding } \\
\text { - Asthenia }\end{array}$ \\
\hline
\end{tabular}

\begin{tabular}{|l|l|l|}
\hline \multicolumn{3}{|l|}{ Table 10. Remote assessment of a child (telephone or online consultation) ([6] as modified by the authors) } \\
\hline Assessment of a child's condition & Intervention & External intervention \\
\hline $\begin{array}{l}\text { Signs and symptoms or their combination } \\
\text { suggest an immediately life-threatening } \\
\text { illness }\end{array}$ & $\begin{array}{l}\text { Immediate referral to emergency hospital } \\
\text { care, call for the appropriate means of } \\
\text { medical transport }\end{array}$ \\
\hline $\begin{array}{l}\text { High risk of a serious illness without imme- } \\
\text { diately life-threatening features }\end{array}$ & $\begin{array}{l}\text { Urgent assessment by a healthcare profes- } \\
\text { sional within 2 hours }\end{array}$ & \\
\hline Intermediate risk of a serious illness & $\begin{array}{l}\text { Direct assessment of the urgency deter- } \\
\text { mined individually by the healthcare profes- } \\
\text { sional carrying out the remote assessment }\end{array}$ & \\
\hline Low risk of a serious illness & $\begin{array}{l}\text { Remote consultation with advice for home } \\
\text { care, determination of management by } \\
\text { parents/carers, including advice on elective } \\
\text { or urgent follow-up criteria, as well as on } \\
\text { how emergency healthcare services can be } \\
\text { accessed }\end{array}$ \\
\hline
\end{tabular}

Temperature, pulse, respiratory rate and capillary refill time measurements should be recorded as part of the routine assessment of a child with fever.

It should be recognised that the signs and symptoms listed are not all the factors that decide on management methods; their coexistence and other factors, e.g. intellectual disability or chronic diseases that affect contact with the child, should be taken into account. Moreover, experience and intuition of the assessing healthcare professional also contribute to ultimate medical decisions.

In practice, assessment of a child and determination of further management is possible as a result of remote consultation, face-to-face advice or a combination of both.

1. Remote consultation (telephone or online advice provided via Internet platforms such as Skype, Zoom, etc.): assessment of a child is performed by a healthcare professional in an indirect manner; therefore, it is mostly based on interpretation of reported symptoms. Nevertheless, the aim is to identify life-threatening fea- tures and the risk of serious illness, as well as to assess possible signs and symptoms of specific diseases and self-limiting conditions. Management procedures are detailed in Table 10.

2. Face-to-face appointment: a child is directly assessed in the ambulatory care setting. A healthcare professional can take a history and perform a physical examination; further management can be determined based on the findings (Table 11).

The healthcare professional decides on the type and place of the child's treatment: ambulatory care with proper precautions or referral to hospital. If hospital admission is unnecessary, but no diagnose has been reached, parents/carers should be provided with verbal and/or written information on warning symptoms that indicate a worsening of the child's condition and how further 24-hour healthcare services (GP, out-of-hours medical assistance, hospital emergency department, emergency medical services) can be accessed. The parents should also be advised that it is necessary to encourage the child to drink more 
fluids (where a baby or child is breastfed, the most appropriate fluid is breast milk) and assess the child for signs of dehydration (dry mouth, sunken fontanelle and eyes, lethargy).

In addition to the child's clinical condition, healthcare professionals should consider the following factors when deciding whether to refer a child to hospital: social and family circumstances, other illnesses that affect the child or other family members, parental anxiety (based on their knowledge of the child), contact with other people who have serious infectious diseases, experience of a previous serious illness or death due to feverish illness which has increased parents' anxiety levels, when a feverish illness has no obvious cause, but the child remains ill longer than expected for a self-limiting illness [6]. Indications for hospital admission are provided in Table 12.

\begin{tabular}{|c|c|c|c|}
\hline $\begin{array}{l}\text { Assessment of a child's condi- } \\
\text { tion }\end{array}$ & Intervention & Additional testing & External intervention \\
\hline $\begin{array}{l}\text { Signs and symptoms or their } \\
\text { combination suggest an imme- } \\
\text { diately life-threatening illness }\end{array}$ & $\begin{array}{l}\text { Intravenous fluids } \\
\text { Active monitoring } \\
\text { Oxygen therapy }\left(\mathrm{SpO}_{2}\right)<92 \%\end{array}$ & & $\begin{array}{l}\text { Immediate referral to emer- } \\
\text { gency medical care, call for the } \\
\text { appropriate means of medical } \\
\text { transport }\end{array}$ \\
\hline $\begin{array}{l}\text { High risk of a serious illness, } \\
\text { localising signs and symptoms }\end{array}$ & & & Urgent hospitalisation \\
\hline $\begin{array}{l}\text { Intermediate risk of a serious } \\
\text { illness, localising signs and } \\
\text { symptoms }\end{array}$ & $\begin{array}{l}\text { Decision on further ambulatory } \\
\text { care } \\
\text { Infants }<3 \text { months of age: tem- } \\
\text { perature, pulse and respiratory } \\
\text { rate monitoring }\end{array}$ & $\begin{array}{l}\text { Decision on ambulatory care: } \\
\text { - Complete blood count with } \\
\text { differential leukocyte count } \\
\text { - CRP level } \\
\text { - Urinalysis, urine culture } \\
\text { - Stool culture when diar- } \\
\text { rhoea } \\
\text { - Chest x-ray when respiratory } \\
\text { signs and symptoms sugges- } \\
\text { tive of pneumonia }\end{array}$ & Possible hospitalisation \\
\hline $\begin{array}{l}\text { Low risk of a serious illness, } \\
\text { localising signs and symptoms }\end{array}$ & $\begin{array}{l}\text { Ambulatory care } \\
\text { Advice for home care, deter- } \\
\text { mination of management by } \\
\text { parents/carers, including advice } \\
\text { on elective or urgent follow- } \\
\text {-up criteria, as well as on how } \\
\text { emergency healthcare services } \\
\text { can be accessed }\end{array}$ & $\begin{array}{l}\text { - Complete blood count with } \\
\text { differential leukocyte count } \\
\text { - CRP level } \\
\text { - Urinalysis } \\
\text { - Stool culture when diar- } \\
\text { rhoea } \\
\text { - Transthoracic ultrasound of } \\
\text { lungs }\end{array}$ & $\begin{array}{l}\text { Children with symptoms and } \\
\text { signs suggesting pneumonia } \\
\text { who are not admitted to hos- } \\
\text { pital should not routinely have } \\
\text { a chest x-ray }\end{array}$ \\
\hline $\begin{array}{l}\text { Children }>3 \text { months of age and/ } \\
\text { /or more signs and symptoms } \\
\text { of a high risk of serious illness } \\
\text { Fever without localising signs } \\
\text { and symptoms }\end{array}$ & $\begin{array}{l}\text { Ambulatory care or hospitalisa- } \\
\text { tion }\end{array}$ & $\begin{array}{l}\text { - Complete blood count } \\
\text { - CRP level } \\
\text { - Urinalysis, urine culture } \\
\text { - Consider: } \\
\text { - Chest x-ray } \\
\text { - Electrolytes, arterial } \\
\text { blood gases } \\
\text { - Transthoracic ultrasound } \\
\quad \text { of lungs }\end{array}$ & Possible hospitalisation \\
\hline $\begin{array}{l}\text { Intermediate risk of a serious } \\
\text { illness } \\
\text { Fever without localising signs } \\
\text { and symptoms }\end{array}$ & Ambulatory care & $\begin{array}{l}\text { - Urinalysis, urine culture } \\
\text { - Complete blood count } \\
\text { - CRP level } \\
\text { - Chest } x \text {-ray in children with } \\
\text { fever }>39^{\circ} \mathrm{C} \text { and } \mathrm{WBC}>20 \\
\times 10^{9} / \mathrm{L} \\
\text { - Transthoracic ultrasound of } \\
\text { lungs }\end{array}$ & $\begin{array}{l}\text { Consider hospitalisation in } \\
\text { children aged }<1 \text { year (lumbar } \\
\text { puncture) }\end{array}$ \\
\hline $\begin{array}{l}\text { Low risk of a serious illness } \\
\text { Fever without localising signs } \\
\text { and symptoms }\end{array}$ & $\begin{array}{l}\text { Ambulatory care } \\
\text { Home care with advice on } \\
\text { the signs and symptoms to be } \\
\text { monitored and when to seek } \\
\text { medical advice }\end{array}$ & $\begin{array}{l}\text { - Urinalysis } \\
\text { - Assessment for pneumonia }\end{array}$ & \\
\hline Infants $<3$ months of age & $\begin{array}{l}\text { Ambulatory care or hospitalisa- } \\
\text { tion } \\
\text { Temperature, pulse and respira- } \\
\text { tory rate monitoring }\end{array}$ & $\begin{array}{l}\text { - Complete blood count } \\
\text { - CRP level } \\
\text { - Urinalysis, urine culture } \\
\text { - Chest x-ray when respiratory } \\
\text { signs and symptoms sugges- } \\
\text { tive of pneumonia } \\
\text { - Transthoracic ultrasound of } \\
\text { lungs }\end{array}$ & $\begin{array}{l}\text { Hospitalisation: } \\
\text { Infants }<1 \text { month of age } \\
\text { Infants } 2 \text { to } 3 \text { months of age } \\
\text { Deterioration of the overall } \\
\text { condition } \\
\text { WBC }<5 \times 10^{9} / \mathrm{L} \text { and }>20 \times \\
10^{9} / \mathrm{L}\end{array}$ \\
\hline
\end{tabular}




\begin{tabular}{|l|l|}
\hline \multicolumn{2}{|l|}{ Table 12. Indications for hospital care ([6] as modified by the authors) } \\
\hline Indication for hospital admission & Admission method \\
\hline Life-threatening condition & Emergent \\
\hline Child with signs of respiratory/cardiac failure & Urgent \\
\hline Children with signs and symptoms of a serious illness & Urgent \\
\hline $\begin{array}{l}\text { Unclear diagnosis and differential diagnosis refer to a potentially serious disease that may require } \\
\text { hospitalisation to prevent further deterioration of a child }\end{array}$ & Urgent \\
\hline Diagnosis suspected but confirmatory tests unavailable in primary care & Urgent \\
\hline $\begin{array}{l}\text { Diagnosis established but treatment unavailable in primary care: children require management } \\
\text { and treatment available only in the hospital setting }\end{array}$ & Urgent \\
\hline $\begin{array}{l}\text { Infants < } 3 \text { months of age with suspected urinary tract infection (without any signs or symptoms } \\
\text { suggesting another focal infection) }\end{array}$ & Urgent \\
\hline $\begin{array}{l}\text { Child with signs of mild or moderate dehydration due to a recent history of gastrointestinal infec- } \\
\text { tion and oral hydration failure }\end{array}$ & Urgent \\
\hline Co-existence of several signs and symptoms of the intermediate risk of serious illness & Urgent / to be decided individually \\
\hline
\end{tabular}

\section{Treatment}

Antipyretic agents belong to the group of most commonly used drugs in daily practice and are available without prescription (OTC). They also demonstrate analgesic effects. Currently administered antipyretics in paediatric care are: ibuprofen (nonsteroidal anti-inflammatory drug, NSAID) with an additional analgesic effect, paracetamol and metamizole [16].

\section{Ibuprofen}

\section{Pharmacodynamic properties}

Ibuprofen is a drug with a complex mechanism of action: analgesic, antipyretic and, additionally, anti-inflammatory effects. It blocks arachidonic acid metabolism by the cyclooxygenase component, acting peripherally and centrally. The mechanism of the central antipyretic effect involves blocking hypothalamic and thalamic cyclooxygenase 2 (COX-2), which leads to inhibition of prostaglandin synthesis [17]. Ibuprofen demonstrates peripheral analgesic properties by inhibiting iNO synthase (NOS-3), as well as activating serotonin and the noradrenalin pathway in the spinal cord. Independently of acting on cyclooxygenase, ibuprofen inhibits intracellular nuclear factor NF-KB involved in regulation of genetic transcription of pro-inflammatory cytokines (IL-6, IL-1, TNF- $\alpha$ ). Through NO (NOS-2) and leukotriene B4 synthases, it activates lipoxines (mainly $A$ type) in the focal inflammatory site; they are endogenous anti-inflammatory and antipyretic mediators which also demonstrate non-cyclooxygenase mechanisms of affecting fever and inflammatory processes. In addition, ibuprofen has the ability to inhibit the permeation of leukocytes (through vascular walls) into inflammatory sites in tissues, as well as reduce congestion and oedema severity $[16,18]$.

\section{Pharmacokinetic properties}

Ibuprofen is a propionic acid derivative which is rapidly absorbed from the stomach following oral administration. An important property of ibuprofen is its short "peripheral" half-life of about 2 hours. Due to its considerable lipophilic nature, ibuprofen is then distributed to the central nervous system, which results in an up to 6-hour antipyretic effect. It should be noted that liquid ibuprofen shows a much quicker antipyretic effect compared to tablets, pills or capsules. In the case of solid dosage forms, ibuprofen must be first released from its solid form and absorbed in the digestive tract. The liquid form is absorbed immediately, which affects its time to reach the maximum antipyretic effect [19].

The rectal route, due to the drug's pharmacokinetic properties, is less effective than oral administration. However, the limited available ibuprofen pharmacokinetic studies show that the bioavailability of this form of ibuprofen dosage is sufficient in children and adults, and blood concentrations of the agent demonstrate therapeutic effects $[20,21]$.

\section{Posology and method of administration}

Due to its excellent safety profile, ibuprofen may be used in children 3 months of age and older and by breast-feeding mothers, as only $1 \%$ of the dose is excreted into the milk. The recommended antipyretic oral and rectal dose is $5-10 \mathrm{mg} / \mathrm{kg}$ per dose. A daily ibuprofen dose of $30 \mathrm{mg} / \mathrm{kg} /$ day should not be exceeded in children weighing up to $35 \mathrm{~kg}$; in children weighing over $40 \mathrm{~kg}$ and in adults, a daily dose of $400 \mathrm{mg}$ every 6 hours (maximum $1600 \mathrm{mg} /$ day) should not be exceeded [22]. Ibuprofen may be taken after fasting to achieve a quicker antipyretic effect [16, $18,19]$.

\section{Safety}

Ibuprofen is considered the safest agent among classical NSAIDs. Clinical practice and studies show that the safety profile of ibuprofen administered for up to 7 days is as beneficial as that of paracetamol. The incidence of adverse effects in children treated with ibuprofen and paracetamol is comparable. Similarly, the ibuprofen gastrointestinal safety profile is comparable to that of paracetamol in the case of short-term use [23]. Ibuprofen demonstrates a beneficial activity profile regarding specific cyclooxygenase isoforms, resulting in a small risk of upper digestive tract and renal injury during its administration. Moreover, short-term inhibition of cyclooxygenase activity reduces the risk of interactions with other drugs where the pharmacodynamic mechanism of action involves arachidonic acid metabolites. Ibuprofen overdose in children is extremely rare and usually occurs when several ibuprofen products are used concomitantly, their administration is not supervised, or the dosage instructions are unclear. In most children with an overdose of ibuprofen alone, the risk of serious adverse effects is small [24, 25]. Long-term use of ibuprofen, at high doses, with significant dehydration, is associated with a risk of acute renal injury; moreover, it is not recommended in the case of varicella or Kawasaki disease [26, 27]. Cases of symptomatic overdose in children were reported following administration of over $440 \mathrm{mg} / \mathrm{kg} /$ day [28]. The risk of ibuprofen nephrotoxicity is small and comparable to that of paracetamol, with proper dosage and short-term use [29]. Moreover, it has been discussed whether the effects of ibuprofen use may mask infection symptoms, leading to delayed treatment initiation and, therefore, worsening of the course of infection.

Such cases were reported for community-acquired bacterial pneumonia and bacterial complications of varicella. The observed (in 7 studies) higher risk of pneumonia complications with ibuprofen may result from the fact it was administered 
more often in children with a more severe disease and longer-lasting fever, and the more frequent use was a marker and not a causative factor of the more serious infection [30].

\section{Paracetamol}

\section{Pharmacodynamic properties}

Paracetamol (acetaminophen) is an analgesic and antipyretic, centrally acting drug which inhibits prostaglandin synthesis at the second stage of arachidonic acid pathway (PGG2 peroxidation to PGH20 through blocking the peroxidase component of the COX-2 isoenzyme). The effectiveness of paracetamol highly depends on the oxyreductive state of tissues [31, 32]. Paracetamo alters the sensitivity of hypothalamic thermoregulatory centre cells to exogenous bacterial and viral as well as endogenous (IL-1, IL- 6 and TNF- $\alpha$ ) pyrogens. The drug also acts on nociceptive sensory neurons in hypothalamus (i.e. third-order sensory neuron). Paracetamol has no anti-inflammatory properties [33].

\section{Pharmacokinetic properties}

The routes of paracetamol administration may be oral, rectal or intravenous. Optimal are the oral and intravenous routes. Rectal use is not recommended due to the paracetamol pharmacokinetic profile [34]. Following oral administration, paracetamol is readily and rapidly absorbed from the gastrointestinal tract, mainly in the small intestine. The onset of action is usually observed after 30 to 60 minutes (15 minutes for liquid dosage forms), and the maximum concentration is reached as early as 10 to 60 minutes after ingestion, with bioavailability of approx. $60 \%$. The antipyretic and analgesic effects are maintained for 6-8 hours and 4-6 hours, respectively [35, 36]. Following rectal administration, paracetamol bioavailability is approx. 50\% lower than that of an oral dosage; what is more, the maximum serum concentration is reached after 2 to 4 hours of ingestion, which considerably reduces the effectiveness of paracetamol [34].

\section{Posology and method of administration}

In children, paracetamol dosage is determined based on weight; the recommended dose is $15 \mathrm{mg} / \mathrm{kg}$ via oral and rectal routes. Paracetamol should be regularly administered every 4 hours without exceeding a daily dose of $60 \mathrm{mg} / \mathrm{kg} / \mathrm{day}$ [22]. It has been found in one study that an initial bolus of $30 \mathrm{mg} / \mathrm{kg}$ ensures a better antipyretic effect than a routine dose of $15 \mathrm{mg} / \mathrm{kg}$, due to more rapid and sustained fever alleviation in children [37].

The dosage range was confirmed by a systematic review of clinical studies, which showed that, compared to $10 \mathrm{mg} / \mathrm{kg}$, a dose of $15 \mathrm{mg} / \mathrm{kg}$ seems to maintain a lower temperature for a longer time and is more effective in reducing the average temperature compared to baseline values $\left(1.6^{\circ} \mathrm{C}\right.$ vs $\left.1.2^{\circ} \mathrm{C}\right)$ [36]. Although the product is licensed for use with no age limitations, it is usually not recommended in children younger than 3 months of age without previous medical consultation, as fever may be the only sign of serious infection in this age group [38]. A frequent problem encountered in daily practice is administration of too small a paracetamol dose, which leads to temperature fluctuations and inadequate analgesic effects.

\section{Safety}

Therapeutic paracetamol doses are safe without hepato- or nephrotoxicity; moreover, the drug may be taken after fasting (no irritation of stomach mucosa) [39-41]. However, it should be recognised that the wide availability of paracetamol (also as a component of fixed-dose combinations) makes it the most common cause of poisoning in children under the age of 6 years [38].

Acute and chronic paracetamol overdose results in gastrointestinal disorders. Possible paracetamol-related adverse effects include hepatic impairment (the overdose may lead to hepatic injury or necrosis, or acute and potentially fatal hepatic failure). Hepatic failure occurs rarely, and the cause of death in this case is mainly considered to be a delay of proper treatment initiation. An overdose may also result in haematological abnormalities (thrombocytopenia, blood cell haemolysis (in patients with glucose-6-phosphate dehydrogenase deficiency), anaphylaxis and severe skin reactions, including Stevens-Johnson syndrome $[19,39,42]$. During routine visits, parents should be advised to be aware of a potential overdose and poisoning risk during home administration of paracetamol and to use fixed-dose combinations with special caution.

\section{Metamizole}

\section{Pharmacodynamic properties}

Metamizole is a non-opioid analgesic with additional antipyretic and spasmolytic effects. Metamizole metabolites inhibit prostaglandin synthesis, primarily by inhibition of cyclooxygenases 1 and 2 (COX-1, COX-2). It demonstrates analgesic and antipyretic properties via the cannabinoid system, which makes it effective when other antipyretics fail. It is estimated that the metamizole antipyretic effect is stronger than that of paracetamol and comparable to NSAID antipyretics due to its influence on cannabinoid receptors and central prostaglandin synthesis $[18,43]$.

\section{Pharmacokinetic properties}

Oral tablets act within 30 to 60 minutes following administration. The bioavailability of metamizole oral drops is $81 \%$, and the onset of the antipyretic effect is observed approx. 15 minutes after ingestion. The recommended oral dose in the population up to 14 years of age is $8-16 \mathrm{mg} / \mathrm{kg}$, and the dosage level depends on fever severity; $10 \mathrm{mg} / \mathrm{kg}$ is usually sufficient. In children 15 years of age or older, a single antipyretic dose is 1,000 $\mathrm{mg}$. In antipyretic interventions, metamizole doses may be administered every 6 to 8 hours, which is equivalent to the maximum daily dose of $4,000 \mathrm{mg}[19,44]$. Administration of a single dose and its value depend on pain or fever severity, as well as individual reactions to metamizole. The minimum therapeutic dose should be applied.

\section{Safety}

In cohort and observational studies, available in recent years, it has been acknowledged that metamizole-induced agranulocytosis is a rare complication, with the incidence comparable to that known for other non-opioid analgesics; nevertheless, the risk is of certain importance $[45,46]$. Metamizole use is also associated with a small risk of interactions with other, concomitantly used drugs. A clinically relevant interaction is observed for cyclosporine; therefore, caution is advised in patients taking both drugs concurrently. It should be noted that according to the current European Medicines Agency statement, definitive rejection of metamizole use in infants younger than 3 months of age is not considered to be justified, as studies in patients of this age group showed no particular risks [45]. Currently, metamizole oral drops are available for the paediatric population. Metamizole is licensed for use in acute severe pain following trauma or surgery, colic, tumour pain, other acute or chronic severe pain if other therapeutic measures are contraindicated and high fever that does not respond to other measures [47].

\section{Effectiveness of antipyretics}

A meta-analysis (2009) assessing the effectiveness of ibuprofen vs paracetamol in reducing fever and alleviating related signs and symptoms in children has demonstrated a slight advantage of ibuprofen at 6 hours following administration and no difference regarding multiple dosing [24]. Studies from 2015 show that the antipyretic and analgesic effects of both agents are similar provided that appropriate, recommended dosing regimens are applied, i.e. $15 \mathrm{mg} / \mathrm{kg} /$ dose for paracetamol and $10 \mathrm{mg} / \mathrm{kg} /$ dose for ibuprofen [48]. A meta-analysis (2020) of 19 


\begin{tabular}{|l|l|l|}
\hline Table 13. Ibuprofen and paracetamol dosing regimens in children [6, 22] \\
\hline Drug and method of administration & Children < $40 \mathrm{~kg}$ & Children $>40-50 \mathrm{~kg}$ and 12 years of age \\
\hline Ibuprofen, oral & $\begin{array}{l}5-10 \mathrm{mg} / \mathrm{kg} \text { every } 6 \text { to } 8 \text { hours } \\
\mathrm{max} 30 \mathrm{mg} / \mathrm{kg} / \mathrm{day}\end{array}$ & $\begin{array}{l}200-400 \mathrm{mg} \text { every } 4 \text { to } 6 \text { hours } \\
\mathrm{max} 1,600 \mathrm{mg} / \mathrm{day}\end{array}$ \\
\hline Ibuprofen, rectal & $\begin{array}{l}10 \mathrm{mg} / \mathrm{kg} \text { every } 6 \text { to } 8 \text { hours } \\
\mathrm{max} 30 \mathrm{mg} / \mathrm{kg} / \mathrm{day}\end{array}$ & $\begin{array}{l}200-400 \mathrm{mg} \text { every } 4 \text { to } 6 \text { hours } \\
\mathrm{max} 1,600 \mathrm{mg} / \text { day }\end{array}$ \\
\hline Paracetamol, oral & $\begin{array}{l}15 \mathrm{mg} / \mathrm{kg} \text { every } 4 \text { hours } \\
\mathrm{max} 60 \mathrm{mg} / \mathrm{kg} / \mathrm{day}\end{array}$ & $\begin{array}{l}700-1,000 \mathrm{mg} \text { every } 4 \text { to } 6 \text { hours } \\
\text { max } 4,000 \mathrm{mg} / \text { day }\end{array}$ \\
\hline Paracetamol, rectal & $\begin{array}{l}15 \mathrm{mg} / \mathrm{kg} \text { every } 4 \text { to } 6 \text { hours } \\
\mathrm{max} 60 \mathrm{mg} / \mathrm{kg} / \mathrm{day}\end{array}$ & $\begin{array}{l}700-1,000 \mathrm{mg} \text { every } 4 \text { to } 6 \text { hours } \\
\text { max } 4,000 \mathrm{mg} / \text { day }\end{array}$ \\
\hline
\end{tabular}

studies (11 with and 8 without randomisation, respectively) in 241,138 participants from 7 countries and various healthcare institutions (hospitals and outpatient clinics) has demonstrated that administration of ibuprofen vs paracetamol for management of fever or pain in children under 2 years of age was associated with reduced temperature and less severe pain within the first 24 hours, with comparable safety [49].

\section{Combination treatment}

Ibuprofen and paracetamol have different mechanisms of antipyretic and analgesic action, and in clinical practice when monotherapy with optimal doses fails to effectively reduce fever, this fact is a basis for considering potential combination therapy, i.e. concomitant or alternating administration of both drugs, to improve therapeutic effects [50]. When attempting administration of ibuprofen and paracetamol combined, we should be aware that concomitant use of both agents results in a synergic effect (being summed but also additionally potentiated), while alternating dosage may lead to drug indifference, which is not beneficial for intensive fever management [50,51]. A systematic review has showed that concomitant administration of ibuprofen and paracetamol in children reduced temperatures to a higher extent at 1 and 4 hours compared to antipyretic monotherapy. Moreover, it was observed that when fever did not resolve or relapsed following a single drug, an alternating dosage of ibuprofen and paracetamol might more effectively reduce the average temperature at one hour following the second dose (mean difference of $0.60^{\circ} \mathrm{C}$ ). In the summary, however, the authors express concerns about the limited assessment of the combination and alternating regimen safety despite no serious adverse reactions reported in literature [52]. In practice, most guidelines restrict indications for combined therapy in children due to the risk of inappropriate dosing regimens or intervals, and they do not recommend alternating or combined administration of ibuprofen and paracetamol (evidence level VI; recommendation strength D) $[6,42,53]$. An alternating dosing regimen in children may only be considered in the case of persistent or recurring anxiety and discomfort for a child [52-55]. In any fever case, a child must be properly hydrated $[16,18]$.

\section{General recommendations $[6,22,42]$}

1. Paracetamol and ibuprofen are antipyretics recommended for use in children (evidence level I; strength of recommendation A). Oral or rectal administration of ibuprofen or paracetamol is recommended [CII].

2. Ibuprofen and paracetamol should be administered at stable intervals and not on an as-needed basis at fever detection time; the minimum therapeutic dose should be applied for the shortest time necessary to alleviate the signs and symptoms, and the drugs should not be used for longer than 3 days except in clearly justified situations.

3. A switch to another treatment should be considered if the child's condition has not improved.
4. A combination of ibuprofen and paracetamol or alternating therapy is not recommended for fever management in children; both drugs should not be administered concomitantly or alternately except in persistent or recurrent anxiety in a child before the next dose (evidence level VI; strength of recommendation $\mathrm{D})$ [CII].

Ibuprofen and paracetamol dosage regimens are outlined in Table 13

\section{Managing treatment failure}

In any case of antipyretic intervention failure, environmental (overheating) or pharmacological (drug-induced fever e.g. due to antibiotic therapy) factors should be considered in terms of treatment ineffectiveness. Although there are no strict guidelines regarding children who may only take paracetamol and ibuprofen products for safety reasons, when proper doses administered do not result in an adequate treatment response, a dual therapy of ibuprofen + paracetamol may be considered provided proper hydration is ensured [6, 22].

Physical interventions take advantage of heat loss through convection or evaporation, while they do not alter the basic thermoregulatory mechanisms. Physical interventions, such as cooling, undressing, cool water sponging or fanning, do not reduce pyrogen levels or affect hypothalamic thermoregulatory mechanisms as observed for antipyretic drugs. During the cooling procedure, the hypothalamic regulatory mechanism maintains a higher set-point temperature; therefore, the physical method, if too active or too rapid, may cause vasoconstriction, an increase in temperature and metabolism and, as a result, rigors that lead to the child crying and having discomfort. Research indicates a beneficial effect of cooling measures providing they are added not earlier than at the beginning of antipyretic-induced resolution of fever, which facilitates removal of excess heat from the body [56].

Physical cooling methods may only be recommended in combination with a previously administered antipyretic agent. Children with fever should be clothed appropriately for their surroundings to avoid hyperthermia or rigors. The main aims are to ensure the comfort of the child and to prevent over-rapid cooling that may cause rigors, which may be distressing for the child and parents [6].

\section{Immunisation}

The beneficial effects of preventive (before vaccination) paracetamol administration have been demonstrated in infants vaccinated against meningococcal group B bacteria [57]. Similar advantages, although diverse due to various vaccination types and order, have been demonstrated in an analysis of 13 randomised studies (2014) [58]. Despite these observations, however, the American Academy of Pediatrics expresses a different position and does not recommend preventive use of paracetamol or ibuprofen to reduce fever and local reactions in vaccinated children (evidence level II; strength of recommenda- 
tions E) [59]. Moreover, the effects of antipyretics on immune response to vaccines have been assessed [60]. The studies have shown that preventive antipyretic administration may affect the immune response, and therefore, it is not recommended [61-63]. This was confirmed by recommendations (2017) where preventive paracetamol or ibuprofen administration to reduce fever incidence and local reactions in vaccinated children is not recommended, with acceptable as-needed post-vaccination use (evidence level II; strength of recommendation E) [42]. In addition, preventive pre-vaccination use of paracetamol or ibuprofen does not reduce the risk of febrile convulsions and is not recommended for this specific purpose (evidence level I; strength of recommendation E) [42, 64, 65]. For post-vaccination fever or local discomfort, scientific societies commonly recommend paracetamol (the only therapeutic option for children younger than 3 months of age) or ibuprofen $[42,65,66]$.

\section{Allergic diseases}

Antipyretics and analgesics in children with allergic diseases were subjected to in-depth analyses. A meta-analysis of $11 \mathrm{co}-$ hort studies assessing the effects of paracetamol used by mothers in the first trimester of pregnancy and in young children with a risk of development of allergic diseases has confirmed the current guidelines on the use of the drug [67]. Administration of a single dose of paracetamol in asthmatic children in a controlled study setting did not result in reduced values of forced expiratory volume in one second $\left(\mathrm{FEV}_{1}\right)$, forced expiratory volume in one second $\%$ of forced vital capacity ( $\left.F E V_{1} / F V C\right)$ and the mean expiratory flow $25-75 \%\left(\mathrm{MEF}_{25-75}\right)$, as well as the increase in FeNO levels [68]. Similarly, a multi-centre, prospective, randomised, double-blind, parallel-group study in 300 children 12 to 59 months of age with mild persistent asthma has demonstrated that ibuprofen or paracetamol used as rescue medications do not increase asthma exacerbation incidence rates or affect other asthma-related complication markers [69] over a one-year observation period. The authors conclude that ibuprofen and paracetamol are not contraindicated in febrile children with asthma, but they are contraindicated in cases of known intolerance to paracetamol or NSAIDs (evidence level I; strength of recommendation A).

It is estimated that NSAID hypersensitivity in children occurs more often than previously considered, which may result from an increasing incidence of allergic diseases and/or frequent cross-reactive allergy phenotypes. These reactions may also appear in children younger than 10 years of age, and in some cases, they include paracetamol (weak COX-3 inhibitor) treatment intolerance. To date, a relationship between NSAID hypersensitivity and chronic urticaria or the role of exacerbating factors, such as viruses, physical exercise and food, has not been well defined. Available data suggests that contrary to adults, severe inflammatory conditions related to nasal polyps and uncontrolled asthma are not observed in the paediatric population [70].

Summing up, it can be concluded that ibuprofen and paracetamol are not contraindicated in children with asthma, but they are contraindicated in known paracetamol- or NSAIDinduced asthma cases (evidence level II; strength of recommendation A) [42].

\section{Infections}

Paracetamol and ibuprofen are commonly used in symptomatic treatment of upper respiratory tract infections. In practice, when paracetamol alone is not sufficient in rhinosinusitis therapy in children older than 6 years of age, fixed-dose combinations are also applied where activation of smooth muscle adrenergic receptors leads to vasoconstriction, thus reducing nasal congestion and oedema. As otalgia results from an en- hanced inflammatory process, ibuprofen with peripheral antiinflammatory and, additionally, central analgesic and antipyretic properties should be immediately administered as first-line treatment unless contraindicated [71-73]. Recommendations for the use of ibuprofen in paediatric patients within the first 24 to 72 hours of otalgia onset have been confirmed by meta-analyses suggesting that ibuprofen is as safe as paracetamol, yet in far higher therapeutic doses than those of paracetamol [74, 75]. Controversies arise about combining available treatments to achieve better treatment outcomes, and there is low-quality evidence of advantages related to a paracetamol/ibuprofen combination compared to paracetamol or ibuprofen monotherapy [73]. Studies conducted in 2020 showed that adding ibuprofen to paracetamol in children to improve analgesic effectiveness does not ensure the expected clinical benefits, which may, however, be associated with suboptimal paracetamol dosing by parents despite strict medical instructions [74]. NSAIDs are not recommended for severe or complicated upper respiratory tract infections with unusual clinical features (duration or signs and symptoms) and not for longer than 72 hours [75].

NSAID use is also the subject of a discussion regarding lower respiratory tract infections. A study in children with bronchiolitis has shown that ibuprofen or ibuprofen with paracetamol administered during the first episode markedly alleviates rhonchi in the later phase compared to children on paracetamol alone [76]. Non-steroidal anti-inflammatory drugs are commonly used for improvement of community-acquired pneumonia signs and symptoms, although no clinical data or guidelines support this kind of management [77]. Krenke et al. have demonstrated that a cumulated ibuprofen dose higher than $78 \mathrm{mg} / \mathrm{kg}$ considerably increases the risk of pulmonary and pleural complications such as: necrotising pneumonia and lung abscess, parapneumonic effusion and pleural empyema $(n=203)$ [78]. Pre-hospitalisation NSAID exposure has also been identified as an independent risk factor of paediatric pleural empyema and other pleural complications in other studies [79, 82]. A review of 10 studies in children and adults where the risk of parenchymal and pleural pneumonia complications, as well as long-term hospitalisation, was assessed did not reveal a risk of NSAID administration, including ibuprofen, due to a possibility of pneumonia complications, highlighting a need for further observational studies [83]. Therefore, there is a suggestion that the necessity and the number of prehospitalisation NSAID doses may be markers rather than reasons of pulmonary or pleural complications in the hospital setting.

\section{Febrile convulsions}

Febrile convulsions are seizures that appear in childhood in children older than 1 month of age and are related to illness accompanied by fever that has not been caused by a central nervous system infection, without previous neonatal seizures or an unprovoked seizure which does not meet the criteria of other acute symptomatic seizures [84].

Febrile convulsions, being a prevailing consequence of fever, are observed in $2 \%$ to $5 \%$ of children of any age, most commonly between 6 months and 5 years of age, with a peak incidence at 18 months of age; they are more frequent in boys and most often occur in the evening $[85,86]$. Febrile convulsions are usually observed when the temperature exceeds $38^{\circ} \mathrm{C}$, although they may appear at any feverish illness time point, while fever itself may occur not earlier than following the episode. Typical signs include: loss of consciousness, breathing difficulty, pallor or cyanosis, foaming at the mouth, eyeballs rolling back, visual fixation, generalised or focal seizures and myoclonic jerking of limbs. A differential diagnosis of febrile convulsions and their classification are presented in Tables 14 and 15.

A child with simple febrile convulsions should not be hospitalised if in a good clinical condition and with a known infec- 


\begin{tabular}{|l|l|}
\hline \multicolumn{2}{|l|}{ Table 14. Differential diagnosis of febrile convulsions $([\mathbf{8 4}, \mathbf{8 5}]$ as modified by the authors) } \\
\hline Condition/sign & Characteristic features \\
\hline Seizure episode & Absence of fever, complex convulsions \\
\hline Rigors & Seizures without loss of consciousness \\
\hline Delirium & Acute and transient fever-related confusion \\
\hline Faint & Short-lasting episode, rapid and complete recovery to normal state, absence of fever \\
\hline Breath holding & Involuntary breath holding by a child and transient loss of consciousness, absence of fever \\
\hline Episodes of anger & Characteristic medical history \\
\hline
\end{tabular}

\begin{tabular}{|c|c|}
\hline Simple febrile convulsions (70\%) & Complex febrile convulsions ( $30 \%$ ) \\
\hline $\begin{array}{l}\text { - Generalised tonic-clonic seizures without focal } \\
\text { features } \\
\text { - Episodes with a duration of less than } 10 \text { minutes } \\
\text { - } \text { Episodes terminating spontaneously } \\
\text { - No recurrence within } 24 \text { hours } \\
\text { Normal findings in additional testing (e.g. EEG, } \\
\text { NMR) }\end{array}$ & $\begin{array}{l}\text { - Focal features (e.g. only one side of the body involved): } 16.1 \% \\
\text { - Episodes with a duration of more than } 10 \text { minutes: } 13.1 \% \\
\text { - Two or more episodes within } 24 \text { hours*: } 13.8 \% \\
\text { - No full recovery observed after } 1 \text { hour } \\
\text { - Post-episode neurological complications } \\
\text { - Possible post-episode short-lasting paralysis (Todd's paralysis) } \\
\text { - Possible status epilepticus development } \\
\text { - Possible necessary anticonvulsant drug intervention to terminate the epi- } \\
\text { sode }\end{array}$ \\
\hline
\end{tabular}

* Some authors identify "simple febrile seizures plus" when more than one episode may appear within 24 hours.

$\mathrm{EEG}=$ electroencephalogram; NMR = nuclear magnetic resonance.

\begin{tabular}{|l|}
\hline Table 16. indications for hospital admission of a child with febrile convulsions, so-called red flags $([\mathbf{6 , 8 4 ]}$ as modified by the authors) \\
\hline Red flags: indications for hospital admission \\
\hline Complex febrile convulsions \\
\hline Presence of meningeal signs (Kernig's sign, Brudzinski sign, neck stiffness) \\
\hline Decreased level of consciousness persisting for longer than 1 hour after the convulsive episode \\
\hline Presence of petechial rash \\
\hline Bulging fontanelle \\
\hline Tachycardia disproportionate to body temperature or persistent tachycardia even following temperature normalisation \\
\hline Signs of moderate to severe respiratory failure (tachypnoea, grunting, low oxygen saturation $<92 \%$, chest indrawing) \\
\hline
\end{tabular}

tion source. The child can be monitored in a hospital emergency department and discharged home after 6 hours following the episode. Most seizures are short-lasting and terminate spontaneously with no need for anticonvulsant treatment. Indications for anticonvulsant treatment are: a duration of seizure longer than 5 minutes, status epilepticus and recurrent seizures. During a convulsive episode, the child should be placed in the recovery position, the airways should be managed and vital signs assessed. Treatment involves symptomatic antipyretics and anticonvulsants (diazepam $0.25 \mathrm{mg} / \mathrm{kg}$ i.v. or rectal $0.5 \mathrm{mg} / \mathrm{kg}$ or lorazepam $0.1 \mathrm{mg} / \mathrm{kg}$ i.v.) to suppress seizures [87]. Drugs may be re-administered after approx. 20 minutes if the seizure does not resolve following the first administration. Proper hydration with cool fluids is also important after seizure termination. The prognosis for simple febrile convulsions is good. The risk of epilepsy development is small, and seizures do not negatively impact the child's behaviour, school progress or neurological disorders. However, complex febrile convulsions increase the risk of epilepsy and recurrent febrile convulsive episodes [88]. Indications for hospital admission of children with febrile convulsions are detailed in Table 16.

Antipyretic agents do not prevent recurrent episodes or febrile convulsions and should not be used specifically for this purpose $[6,89]$. Long-acting anticonvulsants are not recommended as preventive measures, because it has been shown they do not reduce the risk of recurrent episodes or epilepsy, and their possible adverse effects outweigh the potential benefits [85-87]. Prophylactic administration of paracetamol or ibuprofen is not recommended in the prevention of febrile convulsions in children (evidence level I; strength of recommendation E) [42].

\section{COVID-19}

The global SARS-CoV-2 pandemic affects all age groups. Although paediatric cases are far less frequent than those observed among adults, and the clinical course of infection is mild (oligo- or asymptomatic) in $80 \%$ to $90 \%$ of patients, certain groups of children are severely affected, and deaths have been reported even in the youngest age population [90]. Paediatric signs and symptoms are: fever, dry cough, rhinitis, sore throat and fatigue, as well as diarrhoea or emesis in $10 \%$ of cases. Rare cases of dyspnoea or hypoxia and paediatric inflammatory multisystem syndrome temporally associated with COVID-19 have been observed [91]. There are no specific therapies available, and adult treatments (remdesivir, convalescent plasma, tocilizumab) are of limited availability for children. In symptomatic treatment, antipyretic agents are used in addition to hydration and rest [92].

Despite initial concerns based on theoretical rationales and groundless reports in social media, there is no evidence that NSAIDs increase the risk in patients with COVID-19. This has been confirmed by many national authorities and international societies agreeing that there are no arguments suggesting that patients with suspected or confirmed COVID-19 show worse treatment outcomes with ibuprofen (or other NSAIDs) [93-96]. Moreover, the World Health Organization, who informed on 17 March 2020 that patients with COVID-19 should avoid ibuprofen, withdrew their initial recommendations following a quick systematic review of research studies [97]. Children with suspected or confirmed COVID-19 should receive treatment according to accepted guidelines that may involve the use of 
ibuprofen and paracetamol if clinically indicated. Individuals on regular NSAIDs should not discontinue their therapy due to COVID-19 concerns. As in the case of any treatment, benefits and risks of known adverse effects should be considered on an individual basis, and medicinal products should be administered in accordance with their indications and contraindications for use [98].

\section{Summary}

1. In children, fever is a manifestation of a broad illness spectrum, including both frequent self-limiting viral upper respiratory tract infections and serious, life-threatening conditions.

2. Diagnostic evaluation of a feverish child aims to assess the risk of serious illness and life-threatening conditions, as well as signs and symptoms of other specific diseases or self-limiting viral infections, and to apply appropriate medical intervention. It is necessary to determine ambula- tory care indications and proper drug therapy or hospital admission.

3. Paracetamol and ibuprofen are antipyretic agents recommended in paediatric symptomatic treatment, but they are not advised in combination or in alternating therapy except in specific clinical situations. They may be administered for post-vaccination fever and local reactions; however, they are not recommended as preventive measures to reduce fever incidence or local discomfort.

4. Ibuprofen and paracetamol products are not contraindicated in children with asthma, though they must not be administered for asthma induced by NSAID or paracetamol intolerance.

5. Prophylactic administration of paracetamol or ibuprofen is not recommended in the prevention of febrile convulsions in children.

6. Children with suspected or confirmed COVID-19 may be treated with paracetamol and ibuprofen products according to clinical indications and applicable dosing regimens.

APAP for children and Ibuprom for children are partners to Compass 2021 recommendation for fever in children.

\section{References}

1. Campbell D, Deloian B, Clark Vickers M, et al. Infancy visits: first week visit ( 3 to 5 days). In: Hagan JF, Shaw JS, Duncan PM, eds. Bright Futures: guidelines for health supervision of infants, children, and adolescents. 4th ed. Elk Grove Village (IL): American Academy of Pediatrics; 2017: 361-382.

2. Osilla EV, Marsidi JL, Sharma S. Physiology, temperature regulation. In: StatPearls. Treasure Island (FL): StatPearls Publishing; 2020.

3. Sahib El-Radhi A, Carroll J, Klein N, et al. Measurement of body temperature. In: Sahib El-Radhi A, Carroll J, Klein N, eds. Clinical manual of fever in children. Cham: Springer; 2018: 69-84.

4. Ward MA, Hannemann NL. Fever: pathogenesis and treatment. In: Cherry JD, Harrison G, Kaplan SL, et al., eds. Feigin and Cherry's Textbook of pediatric infectious diseases. 8th ed. Philadelphia: Elsevier; 2018: 52-68.

5. Ward MA. Fever in infants and children: pathophysiology and management [cited 2.10.2020]. Available from URL: https://www-1uptodate-1com-100022cdu03b7.han3.wum.edu.pl/contents.

6. NICE Guideline Updates Team (UK). Fever in under 5s: assessment and initial management. London: National Institute for Health and Care Excellence (UK); 2019.

7. Smitherman HF, Macias CG. Febrile infant (younger than 90 days of age): definition of fever [cited 2.10.2020]. Available from URL: https://www-1uptodate-1com-100022cdu03b7.han3.wum.edu.pl/contents.

8. Teller J, Bernasconi R, Simonetti GD, et al. Performance of axillary and rectal temperature measurement in private pediatric practice. Eur J Pediatr 2019; 178: 1501-1505.

9. Chiappini E, Venturini E, Remaschi G, et al. 2016 Update of the Italian Pediatric Society guidelines for management of fever in children. J Pediatr 2017; 180: 177-183.

10. Geijer $\mathrm{H}$, Udumyan $\mathrm{R}$, Lohse $\mathrm{G}$, et al. Temperature measurements with a temporal scanner: systematic review and meta-analysis. BMJ Open 2016; 6: 1-14.

11. Teran CG, Torrez-Llanos J, Teran-Miranda TE, et al. Clinical accuracy of a non-contact infrared skin thermometer in paediatric practice. Child Care Health Dev 2012; 38(4): 471-476, doi: 10.1111/j.1365-2214.2011.01264.x.

12. Section on Clinical Pharmacology and Therapeutics, Committee on Drugs, Sullivan JE, Farrar HC. Fever and antipyretic use in children. Pediatrics 2011; 127: 580-587, doi: 10.1542/peds.2010-3852.

13. El-Radhi AS. Why is the evidence not affecting the practice of fever management? Arch Dis Child 2008; 93: 918.

14. Lin $\mathrm{C}$, Zhang $\mathrm{Y}$, Zhang $\mathrm{K}$, et al. Fever promotes $\mathrm{t}$ lymphocyte trafficking via a thermal sensory pathway involving heat shock protein 90 and $\alpha 4$ integrins. Immunity 2019; 50(1): 137-151, doi: 10.1016/j.immuni.2018.11.013.

15. Biarent D, Bingham R, Richmond S, et al. European Resuscitation Council guidelines for resuscitation 2005. Section 6. Paediatric life support. Resuscitation 2005; 67(Suppl. 1): S97-S133, doi: 10.1016/j.resuscitation.2005.10.010.

16. Dipiro JT, Talbert RL, Mee GC, et al. Pharmacotherapy: a pathophysiologic approach. 10th ed. New York: McGrawHill; 2020.

17. Vane JR, Botting RM. Anti-inflammatory drugs and their mechanism of action. Inflamm Res 1998; 47(Suppl. 2): S78-S87, doi: 10.1007/ s000110050284.

18. Yaffe SJ, Aranda JV. Neonatal and pediatric pharmacology. Philadephia: Lippincott Wiliams \& Wilkins; 2011.

19. Buckingham R, ed. Martindale: the complete drug reference. 40th ed. London: Pharmaceutical Press; 2020.

20. Vilenchik R, Berkovitch M, Jossifoff A, et al. Oral versus rectal ibuprofen in healthy volunteers. J Popul Ther Clin Pharmacol 2012; 19(2): 179-186.

21. Demir N, Peker E, Ece I, et al. Efficacy and safety of rectal ibuprofen for patent ductus arteriosus closure in very low birth weight preterm infants. Matern Fetal Neonatal Med 2017; 30(17): 2119-2125, doi: 10.1080/14767058.2016.1238897.

22. Rekomendacje postępowania w zakażeniach układu oddechowego. Available from URL: http://www.antybiotyki.edu.pl (in Polish).

23. García Rodríguez LA, Jick H. Risk of upper gastrointestinal bleeding and perforation associated with individual non-steroidal antiinflammatory drugs. Lancet 1994; 343: 769-772, doi: 10.1016/s0140-6736(94)91843-0.

24. Volans G, Monaghan J, Colbridge M. Ibuprofen overdose. Int J Clin Pract Supp/ 2003; 135: 54-60.

25. Argentieri J, Morrone K, Pollack Y. Acetaminophen and Ibuprofen overdosage. Pediatr Rev 2012; 33(4): 188-189, doi: 10.1542/pir.334-188.

26. Southey ER, Soares-Weiser K, Kleinen J. Systematic review and meta-analysis of the clinical safety and tolerability of ibuprofen compared with paracetamol in pediatric pain and fever. Curr Med Res Opin 2009; 25(9): 2207-2222, doi: 10.1185/03007990903116255.

27. Misurac JM, Knoderer CA, Leiser JD, et al. Nonsteroidal anti-inflammatory drugs are an important cause of acute kidney injury in children. J Pediatr 2013; 163: 1153-1159. 
28. Hall AH, Smolinske SC, Conrad Fl, et al. Ibuprofen overdose: 126 cases. Ann Emerg Med 1986; 15(11): 1308-1313, doi: 10.1016/s01960644(86)80617-5.

29. Kanabar DJ. A clinical and safety review of paracetamol and ibuprofen in children. Inflammopharmacology 2017; 25(1): 1-9, doi: 10.1007/s10787-016-0302-3.

30. Pharmacovigilance Risk Assessment Committee (PRAC). Dostępny na URL: https://www.ema.europa.eu/en/documents/prac-recommendation/prac-recommendations-signals-adopted-14-17-april-2020-prac-meeting_en.pdf.

31. Garavito RM. The cyclooxygenase-2 structure: new drugs for an old target? Nat Struct Biol 1996; 3: 897-901.

32. Powell W, Rokach J. Biosynthesis, biological effects, and receptors of hydroxyeicosatetraenoic acids (HETEs) and oxoeicosatetraenoic acids (oxo-ETEs) derived from arachidonic acid. Biochim Biophys Acta 2015; 1851(4): 340-355.

33. Graham G, Davies M, Day R, et al. The modern pharmacology of paracetamol: therapeutic actions, mechanism of action, metabolism, toxicity and recent pharmacological findings. Inflammopharmacology 2013; 21(3): 201-232.

34. Scolnik D, Kozer E, Jacobson S, et al. Comparison of oral versus normal and high-dose rectal acetaminophen in the treatment of febrile children. Pediatrics 2002; 110: 553-556.

35. Martino M de, Chiarug A. Recent advances in pediatric use of oral paracetamol in fever and pain management. Pain Ther 2015; 4: 49-168, doi: 10.1007/s40122-015-0040-z.

36. Temple AR, Temple BR, Kuffner EK. Dosing and antipyretic efficacy of oral acetaminophen in children. Clin Ther 2013; 35: 1361-1375.

37. Tréluyer J, Tonnelier S, d'Athis $\mathrm{P}$, et al. Antipyretic efficacy of an initial 30-mg/kg loading dose of acetaminophen versus a $15-\mathrm{mg} / \mathrm{kg}$ maintenance dose. Pediatrics 2001; 108: E73.

38. American Academy of Pediatrics Committee on Drugs. Acetaminophen toxicity i children. Pediatrics 2001; 1089(4): 1020-1024, doi: 10.1542/peds.108.4.1020.

39. Perrott D, Pirra T, Goodenough B, et al. Efficacy and safety of acetaminophen vs ibuprofen for treating children's pain and fever. Arch Pediatr Adolesc Med 2004; 158: 521-526.

40. Lesko SM, Mitchell AA. The safety of acetaminophen and ibuprofen among children younger than two year old. Pediatrics 1999; 104: 951-952.

41. Kramer M, Naimark L, Roberts-Brauer R, et al. Risk and benefits of paracetamol antipyresis in young children with fever of presumed viral origin. Lancet 1991; 337: 591-594.

42. Chiappini E, Venturini E, Remaschi G, et al. 2016 Update of the Italian Pediatric Society guidelines for management of fever in children. J Pediatr 2017; 180: 177-183, doi: 10.1016/j.jpeds.2016.09.043.

43. Leeuw TG de, Dirckx M, Gonzalez CA, et al. The use of dipyrone (metamizol) as an analgesic in children: what is the evidence? A review. Paediatr Anaesth 2017; 27(12): 1193-1201, doi: 10.1111/pan.13257.

44. Metamizol. Charakterystyka produktu leczniczego [cited 4.02.2021]. Available from URL: file:///C:/Users/zdoni/Downloads/Charakterystyka-39669-20190911000000-1146_D-20191010000443.pdf (in Polish).

45. Stanowisko Europejskiej Agencji Leków (EMA). Available from URL: https://www.ema.europa.eu/en/documents/referral/metamizolearticle-31-referral-annex-ii_pl.pdf (in Polish).

46. Kılıç Ö, İşeri Nepesov M, Ulukapı HB, et al. Paediatric agranulocytosis associated with Metamizole treatment. Paediatr Drugs 2020, doi: 10.1007/s40272-020-00431-1.

47. Charakterystyka Produktu Leczniczego Pyralgin, $500 \mathrm{mg} / \mathrm{ml}$, krople doustne (in Polish).

48. Wong T, Stang AS, Ganshorn $\mathrm{H}$, et al. Combined and alternating paracetamol and ibuprofen therapy for febrile children. Evid Based Child Health 2014; 3: 675-729, doi: 10.1002/ebch.1978.

49. Tan E, Braithwaite I, McKinlay CJD, et al. Comparison of aceteminophen (paracetamol) with ibuprofen for treatment of fever or pain in children younger than 2 years; a systemic review and meta-analysis. JAMA Netw Open 2020; 3(10): e2022398, doi: 10.1001/jamanetworkopen.2020.22398.

50. Tallarida RJ, Raffa RB. Testing for synergism over a range of fixe ratio drug combinations. Life Sciences 1996; 58: 23-28.

51. Woroń J, Engel Z, Filipczak-Bryniarska I, et al. Skojarzona farmakoterapia bólu, czyli o zasadach racjonalnej politerapii bólu. Anest Ratow 2012; 6: 381-385 (in Polish).

52. Wong T, Stang AS, Ganshorn H. et al. Combined and alternating paracetamol and ibuprofen therapy for febrile children. Cochrane Database Syst Rev 2013; 10: CD009572.

53. Sherman JM, Sood SK. Current challenges in the diagnosis and management of fever. Curr Opin Pediatr 2012; 24(3): 400-406, doi: 10.1097/MOP.0b013e32835333e3.

54. Hay A, Costelloe C, Redmond N, et al. Paracetamol plus ibuprofen for treatment of fever in children (PITCH): randomized controlled trial. BMJ 2008; 337: a1302, doi: 10.1136/bmj.a1302.

55. Vries F de, Setakis E, Van Staa TP. Concomitant use of ibuprofen and paracetamol a risk of major safety outcomes. Br J Clin Pharmacol 2010; 70: 429-438, doi: 10.1111/j.1365-2125.2010.03705.x.

56. Meremikwu M, Oyo-Ita A. Physical methods for treating fever in children. Cochrane Database Syst Rev 2003; 2: CD004264. 98.

57. Prymula R, Esposito $S$, Zuccotti GV, et al. A phase 2 randomized controlled trial of a multicomponent meningococcal serogroup $B$ vaccine (I). Hum Vaccin Immunother 2014; 10: 1993-2004, doi: 10.4161/hv.28666.

58. Das RR, Panigrahi I, Naik SS. The effect of prophylactic antipyretic administration on post-vaccination adverse reactions and antibody response in children: a systematic review. PLOS ONE 2014; 9(9): e106629, doi: 10.1371/journal.pone.0106629.

59. Kimberlin DW, Brady MT, Jackson MA, et al., eds. Red book: 2015 report of the committee on infectious diseases. 30th ed. Elk Grove Village (IL): American Academy of Pediatrics; 2015.

60. Purssell E. Cyclooxygenase inhibitors inhibit antibody response through interference with MAPK/ERK pathways and BLIMP-1 inhibition. Med Hypotheses 2014; 83: 372-377, doi: 10.1016/j.mehy.2014.06.015.

61. Duke University, Centers for Disease Control and Prevention. The effect of prophylactic antipyretics on immune responses and fever after 2014-2015 and 2015-2016 inactivated influenza vaccine. In: ClinicalTrials.gov [Internet]. Besthesda (MD): National Library of Medicine; 2014.

62. Walter EB, Hornok CP, Grohskopf L, et al. The effect of antipyretics on immune response and fever following receipt of inactivated influenza vaccine in young children. Vaccine 2017; 35: 6664-6671, doi: 10.1016/j.vaccine.2017.10.020.

63. Kroger AT, Duchin J, Vázquez M. General Best Practice Guidelines for Immunization. Best practices guidance of the Advisory Committee on Immunization Practices (ACIP). Atlanta (GA): US Department of Health and Human Services, Centers for Disease Control and Prevention; 2017, doi: 10.1111/ajt.14683.

64. Rosenbloom E, Finkelstein $\mathrm{Y}$, Adams-Webber T, et al. Do antipyretics prevent the recurrence of febrile seizures in children? A systematic review of randomized controlled trials and meta-analysis. Eur J Paediatr Neurol 2013; 17(6): 585-588, doi: 10.1016/j.ejpn.2013.04.008.

65. General recommendations on immunization: recommendations of the Advisory Committee on Immunization Practices (ACIP). MMWR 2011; 60(2): 16. Dostępny na URL: http://www.cdc.gov/mmwr/pdf/rr/rr6002.pdf. 
66. Kimberlin DW, Brady MT, Jackson MA, et al., eds. Red book: 2015 report of the committee on infectious diseases. 30th ed. Elk Grove Village (IL): American Academy of Pediatrics; 2015.

67. Cheelo M, Lodge CJ, Dharmage SC, et al. Paracetamol exposure in pregnancy and early childhood and development of childhood asthma: a systematic review and meta-analysis. Arch Dis Child 2015; 100(1): 81-89, doi: 10.1136/archdischild-2012-303043.

68. Soferman R, Tsivion A, Farber M, et al. The effect of a single dose of acetaminophen on airways response in children with asthma. Clin Pediatr (Phila) 2013; 52(1): 42-48, doi: 10.1177/0009922812462764.

69. Sheehan WJ, Mauger DT, Paul IM, et al. Acetaminophen versus Ibuprofen in young children with mild persistent asthma. N Engl J Med 2016; 375(7): 619-630, doi: 10.1056/NEJMoa1515990.

70. Kidon M, Blanca-Lopez N, Gomes E, et al. EAACl/ENDA Position Paper: diagnosis and management of hypersensitivity reactions to non-steroidal anti-inflammatory drugs (NSAIDs) in children and adolescents. PAI 2018; 29(5): 469-480, doi: 10.1111/pai.12915.

71. Bertin $L$, Pons $\mathrm{G}$, d'Athis $\mathrm{P}$, et al. A randomized, double blind, multicentre trial on ibuprofen, acetaminophen and placebo for symptoms of acute otitis media. Fundam Clin Pharmacol 1996; 10: 387-392.

72. Narayan K, Cooper S, Morphet J, et al. Effectiveness of paracetamol versus ibuprofen administration in febrile children: a systematic literature review. Paediatr Child Health 2017; 53(8): 800-807, doi: 10.1111/jpc.13507.

73. Sjoukes A, Venekamp RP, Pol AC van de, et al. Paracetamol (acetaminophen) or non-steroidal anti-inflammatory drugs, alone or combined, for pain relief in acute otitis media in children. Cochrane Database Syst Rev 2016, doi: 10.1002/14651858.

74. Uum RT van, Venekamp RP, Zuithoff NP, et al. Improving pain management in childhood acute otitis media in general practice: a cluster randomised controlled trial of a GP-targeted educational intervention. Br J Gen Pract 2020; 70(699): e684-e695, doi: 10.3399/ bjgp20X712589.

75. Truffert E, Fournier Charrière E, Treluyer J-M, et al. Guidelines of the French Society of Otorhinolaryngology (SFORL): nonsteroidal anti-inflammatory drugs (NSAIDs) and pediatric ENT infections. Short version. Eur Ann Otorhinolaryngol Head Neck Dis 2019; 136(4): 289-294, doi: 10.1016/j.anorl.2019.04.001.

76. Skehin K, Thompson A, Moriarty P. Is use of ibuprofen safe in children with signs and symptoms of lower respiratory tract infection? Arch Dis Child 2020; 105(4): 408-410, doi: 10.1136/archdischild-2019-318217.

77. Voiriot $\mathrm{G}$, Philippot $\mathrm{Q}$, Elabbadi A, et al. Risks related to the use of non-steroidal anti-inflammatory drugs in community-acquired pneumonia in adult and pediatric patients. J Clin Med 2019; 8(6): 786, doi: 10.3390/jcm8060786.

78. Krenke K, Krawiec M, Kraj G, et al. Risk factors for local complications in children with community-acquired pneumonia. Clin Respir J 2018; 12(1): 253-261, doi: 10.1111/crj.12524.

79. François P, Desrumaux A, Cans C, et al. Prevalence and risk factors of suppurative complications in children with pneumonia. Acta Paediatr 2010; 99(6): 861-866, doi: 10.1111/j.1651-2227.2010.01734.x.

80. Byington CL, Spencer LY, Johnson TA, et al. An epidemiological investigation of a sustained high rate of pediatric parapneumonic empyema: risk factors and microbiological associations. Clin Infect Dis 2002; 34(4): 434-440, doi: 10.1086/338460.

81. Le Bourgeois M, Ferroni A, Leruez-Ville M, et al. Nonsteroidal anti-inflammatory drug without antibiotics for acute viral infection increases the empyema risk in children: a matched case-control study. J Pediatr 2016; 175: 47-53, doi: 10.1016/j.jpeds.2016.05.025.

82. Elemraid MA, Thomas MF, Blain AP, et al. (North East of England Pediatric Respiratory Infection Study Group Newcastle upon Tyne, UK). Risk factors for the development of pleural empyema in children. Pediatr Pulmonol 2015; 50(7): 721-726, doi: 10.1002/ppul.23041.

83. Sodhi M, Khosrow-Khavar F, FitzGerald JM, et al. Non-steroidal anti-inflammatory drugs and the risk of pneumonia complications: a systematic review. Pharmacotherapy 2020; 40(9): 970-977, doi: 10.1002/phar.2451.

84. Chin RFM, Neville BGR, Peckham C, et al. Incidence, causes, and short-term outcome of convulsive status epilepticus in childhood: prospective population-based study. Lancet 2006 15; 368(9531): 222-229, doi: 10.1016/S0140-6736(06)69043-0.

85. Laino D, Mencaroni E, Esposito S. Management of pediatric febrile seizures. Int J Environ Res Public Health 2018; 15(10): 2232, doi: 10.3390/ijerph15102232.

86. Sahib El-Radhi A, Ferrie C. Febrile seizures. In: Sahib El-Radhi A, Carroll J, Klein N, eds. Clinical manual of fever in children. Cham: Springer; 2018: 179-192.

87. Leung AK, Hon KL, Leung TN. Febrile seizures: an overview. Drugs Context 2018; 7: 2125. Available from URL: https//www.drugsincontext.com/febrile-seizures-an-overview/.

88. Camfield P, Camfield C. Febrile seizures and genetic epilepsy with febrile seizures plus (GEFS+). Epileptic Disord 2015; 17(2): 124-133, doi: 10.1684/epd.2015.0737.

89. Kimia AA, Bachur RG, Torres A, et al. Febrile seizures: emergency medicine perspective. Curr Opin Pediatr 2015; 27(3): 292-297, doi: 10.1097/MOP.0000000000000220.

90. Goldman RD. Coronavirus disease 2019 in children: surprising findings in the midst of a global pandemic. Can Fam Physician 2020; 66(5): 332-334.

91. Harwood R, Allin B, Jones CE, et al. PIMS-TS National Consensus Management Study Group. A national consensus management pathway for paediatric inflammatory multisystem syndrome temporally associated with COVID-19 (PIMS-TS): results of a national Delphi process. Lancet Child Adolesc Health 2020, doi: 10.1016/S2352-4642(20)30304-7.

92. Xu X, Ong YK, Wang Y. Role of adjunctive treatment strategies in COVID-19 and a review of international and national clinical guidelines. Mil Med Res 2020; 7(1): 22, doi: 10.1186/s40779-020-00251-x.

93. U.S. Food and Drug Administration FDA Advices Patients of Use of NSAIDs for COVID-19. United States of America: FDA; 2020 [cited 20.12.2020]. Available from URL: https://www.fda.gov/drugs/drug-safety-and-availability/fda-advises-patients-use-non steroidal-antiinflammatory-drugs-nsaids-covid-19.

94. European Medicines Agency. EMA gives advice on the use of non-steroidal anti inflammatories for COVID-19. Netherlands: EMA; 2020 [cited 20.12.2020]. Available from URL: https://www.ema.europa.eu/en/news/ema-gives-advice-use-non-steroidal-anti-inflammatories-covid-19.

95. National Institute for Healthcare and Excellence. COVID-19 rapid evidence summary: acute use of non-steroidal anti-inflammatory drugs (NSAIDs) for people with or at risk of COVID-19 United Kingdom: NICE; 2020 [cited 20.12.2020]. Available from URL: https:// www.nice.org.uk/advice/es23/chapter/Key-messages.

96. Therapeutic Goods Administration. No evidence to support claims ibuprofen worsens COVID-19 symptoms. Australia: TGA; 2020 [cited 20.12.2020]. Available from URL: https://www.tga.gov.au/alert/no-evidence-support-claims-ibuprofen-worsens-covid-19-symptoms.

97. World Health Organization. The use of non-steroidal anti-inflammatory drugs (NSAIDs) in patients with COVID-19. Geneva: WHO; 2020 [cyt. 20.12.2020]. Dostępny na URL: https://www.who.int/news-room/commentaries/detail/the-use-of-non-steroidal-anti-inflammatory-drugs-(nsaids)-in-patients-with-covid-19.

98. Martins-Filho PR, Nascimento-Júnior EM do, Santos VS. No current evidence supporting risk of using Ibuprofen in patients with COVID-19. Int J Clin Pract 2020; 74(10): e13576, doi: 10.1111/ijcp.13576. 
Tables: 16

Figures: 0

References: 98

Received: 11.01.2021

Reviewed: 13.01.2021

Accepted: 22.02.2021

Address for correspondence:

Zbigniew Doniec, MD, PhD, Assoc. Prof.

Klinika Pneumonologii

Instytut Gruźlicy i Chorób Płuc OT w Rabce-Zdroju

ul. Prof. J. Rudnika 3B

34-700 Rabka Zdrój

Polska

Tel.: +48 18 267-60-60

E-mail: zdoniec@igrabka.edu.pl 